\title{
Existence of Antibiotics in Stalls at Jatiroke Village, Jatinangor Sub District
}

\author{
Elan Jaelani, ${ }^{1}$ Istriati, ${ }^{2}$ Deni Kurniadi Sunjaya ${ }^{3}$ \\ ${ }^{1}$ Faculty of Medicine Universitas Padjadjaran, ${ }^{2}$ Department of Pharmacology and Therapy \\ Faculty of Medicine, Universitas Padjadjaran, ${ }^{3}$ Department of Public Health Faculty of Medicine \\ Universitas Padjadjaran
}

\begin{abstract}
Background: Improper use of antibiotics can lead to lack of drug efficacy against bacteria, and cause resistance to the antibiotics itself. Antibiotics are classified into prescription drugs that should not be available over the counter because of its dangerous effect. It is important to study the presence of antibiotics in traditional stalls. Objective of this study was to investigate existence of antibiotics in stalls, and to investigate reasons of stall- owners for selling antibiotics.

Methods: This study used mixed method design, and sequential explanatory approach, and conducted direct observation, spatial mapping, and interview with stall-owners selling drugs in Jatiroke village, Jatinangor sub district from September to November 2013. Total sampling was conducted in this study.

Results: Fifty percent from 24 surveyed stalls sold Antibiotics Amoxicillin. The map showed stalls selling antibiotics at roadside. Amoxicillin sold package with Dexamethasone and Non-Steroid Anti Inflammatory Drugs (NSAID) was soldby several stalls. Shopkeepers sold antibiotics due to lack of knowledge about the drug, need for self-medication, demand, and availability of drugs supply.

Conclusions: Antibiotics can be found in several stalls in Jatiroke village, and improper of use of this drug can lead to resistance and less efficacy for treating infections. Although the Act for prescription drugs still exists, low of monitoring and enforcement the regulation by the Badan Pengawas Obat dan Makanan (BPOM) may be one of many factors that influence the existence of antibiotics in the stalls. [AM].2016;3(2):239-43]
\end{abstract}

Keywords: Antibiotics, existence, Jatiroke, stalls

\section{Introduction}

Antimicrobial resistance is an increasing global crisis in developing countries. Antibiotic use, particularly over the counter, is widespread. ${ }^{1}$ Various kinds of bacteria that are resistant to antibiotics have been found almost all over the world. ${ }^{2}$ In poor countries there are multiresistant pathogens such as Mycobacterium tuberculosis, Pneumococci, Uropathogenic Escherichia coli (UPEC), and Salmonella. Some studies in Indonesia conducted by Lestari et al. ${ }^{1}$ and Duerink et al. ${ }^{4}$ presented antibiotic resistant Escherichia coli and Staphylococcus aureus. From 3.275 individuals $54 \%$ has carried resistant Escherichia coli.

Antibiotics are classified into prescription drug classes. ${ }^{5}$ Antibiotics can only be given by the pharmacy with prescription from a doctor. ${ }^{6}$
Many people take self medication which will increase the possibility of any improper use of antibiotics. ${ }^{7}$ Meanwhile, antibiotics can be easily obtained from a pharmacy without a doctor's prescription, from stalls and drug stores that do not have a license to sell antibiotics. Research data in Surabaya showed approximately 39 stalls are selling antibiotics. ${ }^{8}$

The objective of this study was to investigate the existence of antibiotics in stalls which were sold freely, and to investigate the reason of the stall owners for selling antibiotics.

\section{Methods}

This study were food stalls that were selling drugs, and were willing to participate in the study by signing an informed consent form. A total of 24 stalls were included in the study,

Correspondence: Elan Jaelani, Faculty of Medicine, Universitas Padjadjaran, Jalan Raya Bandung-Sumedang Km.21, Jatinangor, Sumedang, Indonesia, Phone: 085353032556 Email: j.elan25@gmail.com 
and the total sampling was performed in this study. There were no inclusion or exclusion criteria for the stalls.

This study used the mixed method, sequential explanatory (quantitativequalitative) type of study. Meaning that the study collected observation quantitative data on the presence of antibiotics in the stalls first, then proceed with digging out qualitative data on reasons for selling antibiotics. This study also used spatial analysis with the Global Positioning System (GPS) Garmin to see the distribution of stalls selling antibiotics.

Furthermore, the quantitative data were analyzed using the Microsoft Office Excel 2007 program and Health Mapper program, then displayed as percentages and spatial maps. The qualitative data were analyzed with thematic analysis that incorporated the findings from the interviews about the reasons presented by the shop-owners, and which were later proved by the behavioral theory.

\section{Results}

The study revealed that $12 / 24$ stalls sold the antibiotic drug Amoxicillin $500 \mathrm{mg}$. Table 1 shows the interview results from the merchants.

All the stalls sold Amoxicillin $500 \mathrm{mg}$ both generic and patent/trade mark. The average of selling antibiotics in a stall could reach up to
20-40 caplets every month, or about 3 blisters of Amoxicillin $500 \mathrm{mg}$. The price offered by the stall- owners was around Rp750-Rp1000 for each caplet.

From the direct observation, Amoxicillin $500 \mathrm{mg}$ with a total of 682 caplets was found in 9 stalls, and 3 stalls were out of stock. Spatial analysis was performed to find out the distribution of antibiotics vendors

Amoxicillin was sold by the stall- owners in retail, about 1-3 items. It wassometimes combined with dexamethasone and mefenamic acid. Obviously, it can be more dangerous than antibiotics if these drugs were inappropriately used. At the time of the survey, several open questions about reasons for selling antibiotics were given to the stall- owners. The data described reasons expressed by the stallowners.

From the 12 stall-owners who were selling antibiotics, no one could explain the definition, function, and the use of antibiotics. Although one of them gave a statement that antibiotics weredrugs for bacteria, but she could not explain more about theuse of antibiotics. Most of the answers were "to cure itching, pain relief, toothache, and for chicken supplement". Moreover, it could be seen from the way of selling, most of them retailed the antibiotics per 3 caplets, or even per 1 caplet without giving any information about the dosage to the customers.

All stall-owners who sold antibiotics,

Table 1 Interview Results

\begin{tabular}{lc}
\hline \multicolumn{1}{c}{ Variable } & Quantity of stalls n=12 \\
\hline Antibiotics Sources & 1 \\
Pharmacy & 2 \\
Salesman & 1 \\
Grocery & 5 \\
Pharmacy, Grocery & 1 \\
Salesman, Grocery & 2 \\
Pharmacy, salesman & \\
Profit & 1 \\
$<20.000$ & 5 \\
$20.000-40.000$ & 6 \\
$>40.000$ & \\
Customer & 6 \\
Neighbors, Families & 5 \\
Neighbors & 1 \\
Retailer & \\
\hline
\end{tabular}




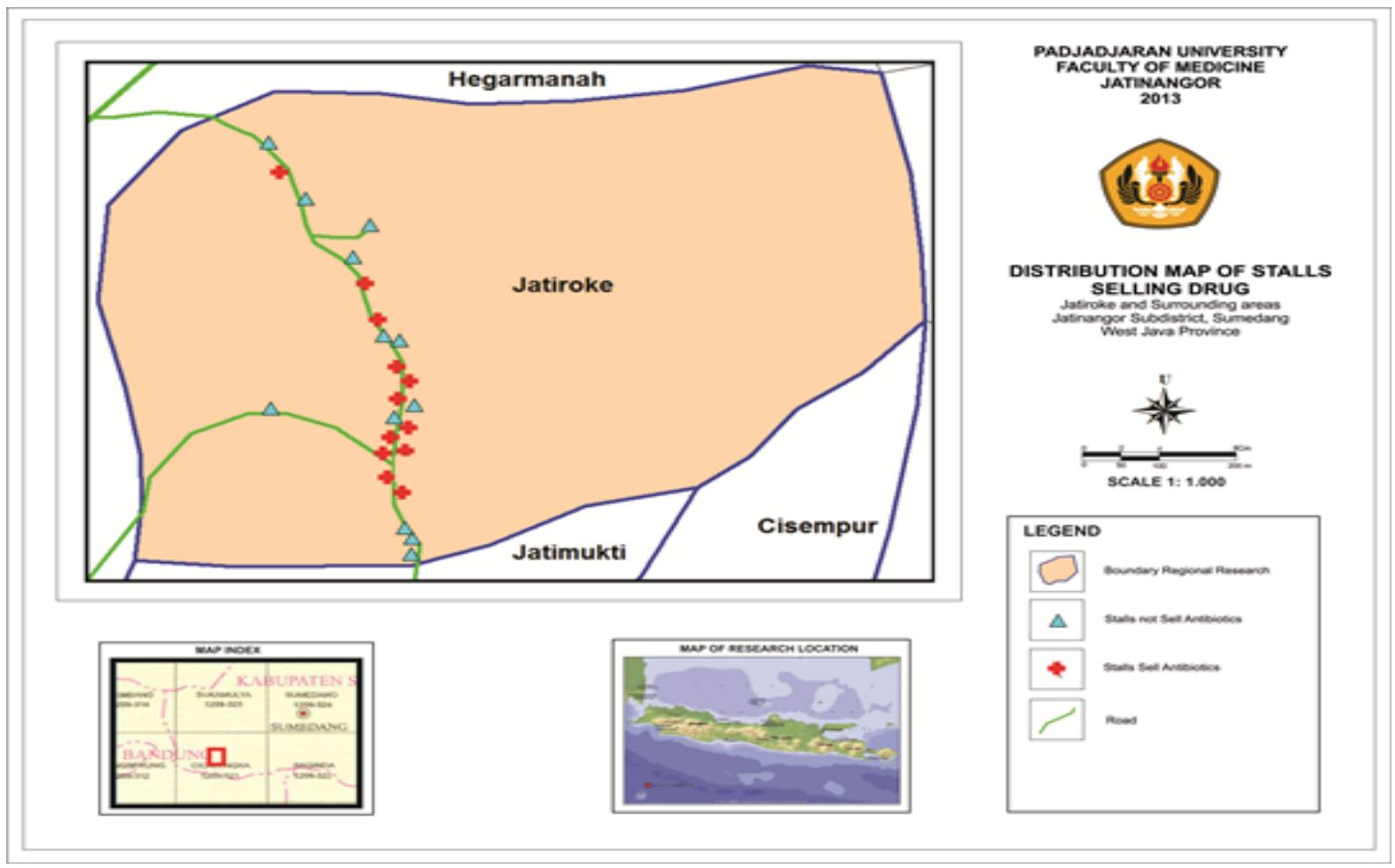

Note: The map shows the distribution of stalls which sold antibiotics (+) and did not sell antibiotics (?).

Figure 1 Spatial Mapping of Stalls Distribution

initially had no intention to sell them, however after requests, some offerings (salesman) came, and their knowledge that doctors and other health providers often gave antibiotics Amoxicillin. It means, the intention for selling antibiotics existed after the request, supply, and their knowledge.

Several stall-owners also took antibiotics when they themselves or their family members got ill, but most of them preferred to visit health-care facilities such as theprimary health centers, physicians, and other health professionals. It means that they also need antibiotics for self-medication.

All stall-owners of stalls selling antibiotics stated that they sold antibiotics because of the demand of residents/neighbors/community around their stall. A total of 7 stall-owners selling antibiotics admitted that they had been offered by a salesman, and sometimes purchased the antibiotics from thesalesman. Several stall-owners also told that some family members gave suggestions to sell antibiotics in theirs stalls. It means that the demand, supply and suggestions influenced the stall-owners to sell antibiotics Amoxicillin.

\section{Discussions}

The results of this was in line with a study conducted in Surabaya by Hadi et al. ${ }^{8}$ The stallowner's lack of knowledge caused customers who bought antibiotics from their stalls did not obtain the right information about the use of antibiotics.

Antibiotics are prescription drugs which have been set out in the Act of Prescription Drugs (st. no. 419 th. 22, 1949) section 3. This act states that drugs listed in Gevaarlijk (G) should not be used for personal use, and may not be given without a prescription from a doctor. Based on the Health Ministry decree No. 167/KAB/B.VIII/1972 about drug retailers, stalls in this case drug retailers can only sell drugs listed in Waarschuwing (W) and over the counter (OTC).

The Ministry of Health has developed guidelines for the use of antibiotics in the Health Ministry decree No.2406/MENKES/ PER/XII/2011. ${ }^{6}$ This guide is intended to protect the public from the improper use of antibiotics. All the reasons expressed by the sellers showed no indication that they had to 
sell antibiotics. It was more about the profit because of their customer's demand. Antibiotic use was only up to three times (three items) meaning, they did not achieve a minimum of antibiotic treatment. It can cause resistance and ineffectiveness of antibiotics. ${ }^{7}$

Antibiotics could be easily obtained by the stall-owners. They could be bought at the pharmacy without a prescription, such as was described in the studies conducted by Hadi et al. ${ }^{8}$, and Puspitasari et al. ${ }^{9}$, as well as in food groceries, and sometimes there were the salesmen who supply the antibiotics. This means that the regulation which should be applied to these antibiotics was not going well.

Furthermore, stalls selling antibiotics were violating the rules. Behavior of selling antibiotics was changed from behavior of not selling antibiotics. This behavior can be formed by a variety of things, among others by the theory of behavioral change among stimulus theory, dissonance, function, Kurt Lewin, and theory of action reasons. ${ }^{10}$

According to the theory of the stimulus by Skinner, the behavior change is due to the stimulus, which is backed by the support facilities, and environment encouragement. This study found that the stimulus-backed demand of customers with ease of getting antibiotics, and driven by the absence of prohibiting the sale of antibiotics. ${ }^{10}$

According to the dissonance theory, behavioral change occurs because of imbalance between elements of cognition (knowledge) of a person. Almost all stall-owners selling antibiotics have less knowledge of antibiotics. ${ }^{10}$

According to the functional theory, behavioral change depends on the need. Based on the interviews, most of the sellers stated that they needed these antibiotics when a family member was ill. ${ }^{10}$

According to Kurt Lewin's theory, behavioral change happened when there is imbalance between the driving force and the restraining force. The driving forces of behavior for antibiotics selling were the customer's demand, supplier, and easiness of getting antibiotics. Meanwhile, the restraining forces are lack of knowledge and lack of supervision of related parties. ${ }^{10}$

The theory of the cause of action stated that behavioral change is influenced by the attitude, desire, and faith. The will is the dominant factor, and is influenced by subjective norms (costbenefit). The stall-owners initially did not have any intention or desire to sell antibiotics, but after demands from customers, and the offer from the supplier raises intention to sell antibiotics. ${ }^{10}$

The existence of antibiotics in stalls was inappropriate with the regulation of antibiotics distribution. It may be due to monitoring and enforcement of the regulation was not running because the Badan Pengawas Obat dan Makanan (BPOM or the Food and Drug Administration) as the one responsible for distribution of drugs is only available at the province level, thus they cannot reach the traditional stalls. Actually, the stalls are at the road side, and reachable for monitoring the antibiotics sold in the traditional stalls.

This study only investigated the stalls and the owners; it needed triangulation for the qualitative study of the costumers, supplier, Health District, and BPOM. However, the triangulation was not conducted in this study, because it was hampered by time limitations, human resource, and financial resource.

In conclusion, antibiotics can be found in several stalls in Jatiroke village, and improper of use of this drug can lead to resistance and less efficacy for treating infections. Although the Act for prescription drugs still exists, low of monitoring and enforcement the regulation by the BPOM may be one of many factors that influence the existence of antibiotics in the stalls.

Stalls selling antibiotics can be formed because it is preceded by a demand from its customers; reinforced by the lack of knowledge about antibiotics; facilitated by the availability of antibiotics in the wholesale (grocery), salean, and pharmacies (purchased OTC).

The BPOM should cooperate with the Health District or other parts to run the stewardship function for repairing the Health system and giving education to the community about the prescription of drugs. Assertiveness should be implemented to those involved in selling freely antibiotics in stalls, or to those who are acting against the existing rules.

\section{References}

1. Lestari E, Severin J, Filius P, Kuntaman K, Duerink D, Hadi U, et al. Antimicrobial resistance among commensal isolates of Escherichia coli and Staphylococcus aureus in the Indonesian population inside and outside hospitals. Eur J Clin Microbiol Infect Dis. 2008;27(1):45-51.

2. Pradono J, Senewe F, Kristianti CM, Sumantri S. Transisi Kesehatan di Indonesia: kajian data surkernas. Jurnal Ekologi Kesehatan. 2005;4(3):336-50.

3. Amábile-Cuevas CF. Antibiotic resistance 
in Mexico: a brief overview of the current status and its causes. J Infect Dev Ctries. 2010;4(3):126-31.

4. Duerink DO, Lestari ES, Hadi U, Nagelkerke $\mathrm{N}$, Severin JA, Verbrugh HA, et al. Determinants of carriage of resistant Escherichia coli in the Indonesian population inside and outside hospitals. J Antimicrob Chemother. 2007;60(2):37784.

5. Fernandes BAM. Study penggunaan antibiotik tanpa resep di kabupaten Manggarai dan Manggrai Barat-NTT. Calyptra: Jurnal Ilmiah Mahasiswa Universitas Surabaya. 2013:2(2):1-17.

6. Kementerian Kesehatan RI. Peraturan Menteri Kesehatan Republik Indonesia No. 2406/MENKES/PER/XII/2011 Tentang Pedoman Umum Penggunaan Antibiotika.
Jakarta: Kementerian Kesehatan RI; 2011.

7. Utami ER. Antibiotika, resistensi, dan rasionalitas terapi. El-Hayah. 2011;1(4):191-8.

8. Hadi U, Van den Broek P, Kolopaking EP, Zairina N, Gardjito W, Gyssens IC. Cross-sectional study of availability and pharmaceutical quality of antibiotics requested with or without prescription (Over The Counter) in Surabaya, Indonesia. BMC Infect Dis. 2010;10:203.

9. Puspitasari HP, Faturrohmah A, Hermansyah A. Do Indonesian community pharmacy workers respond to antibiotics requests appropriately?. Trop Med Int Health. 2011;16(7):840-6.

10. Notoatmodjo S. Promosi kesehatan dan perilaku kesehatan. Jakarta: Rineka Cipta; 2012. 